\title{
CLINICAL CHARACTERISTICS OF COVID-19 IN CHILDREN AT THE INSTITUTE FOR PULMONARY DISEASES IN CHILDREN-SKOPJE
}

\author{
Tatjana Jakovska ${ }^{1}$, Angelcho Andonovski ${ }^{1}$, Eli Stojanova ${ }^{1}$, Biljana Kakaraskoska-Boceska² \\ Institute for Pulmonary Diseases in Children, Skopje, Republic of North Macedonia \\ Institute of Public Health of Republic of North Macedonia, Skopje, Republic of North Macedonia
}

Citation: Jakovska T, Andonovski A, Stojanova E Kakaraskoska-Boceska B. Clinical characteristics o COVID-19 in children at the Institute for Pulmonar Diseases in Children-Skopje. Arch Pub Health 2020 12 (3). https://doi.org/10.3889/aph.2020.5413

Key words: COVID-19, children, pulmonary disease, real-time reverse transcription polymerase chain reaction, macrolides.

*Correspondence: Tatjana Jakovska. Institute for Pulmonary Diseases in Children, Skopje, Republic of North Macedonia E-mail: maretti98@yahoo.com Received: 17-May-2020; Revised: 28-Jun-2020; Accepted: 5-Jul-2020; Published: 15-Dec-2020

Copyright: ${ }^{-2020}$. Tatjana Jakovska. This is an open-access article distributed under the terms of the Crentive Commons Attribution License, which permits unrestricted use, distribution, and reproduction in any medium, proviled the original auduction in any medium, provided th

Competing Interests: The author have declared that no competing interests

\section{Abstract}

The aim of the paper was to evaluate clinical characteristics of COVID-19 in children and the success of the treatment. Material and methods: The study included 218 pediatric patients suspected for COVID-19 hospitalized at the Institute for Pulmonary Diseases in Children-Skopje, during the period from 16th of March to 19th of June 2020. All patients were tested for presence of SARS-CoV-2 virus in nasopharyngeal swab with real-time reverse transcription polymerase chain reaction (RT-PCR) in the Institute of Public Health of Republic of North Macedonia. Clinical symptoms, X-ray and laboratory findings were included in the study. Results: From 218 hospitalized patients, only 9 (4.13\%) were positive for COVID-19 and 59\% of them were males. Infants, with moderate pulmonary disease were $44.4 \%$ of the patients. Fever and gastrointestinal symptoms were present in $66.6 \%$ and $22.2 \%$ of the children, respectively. Macrolides were therapy of choice in $88 \%$ of the treated patients, $77 \%$ received intravenous therapy, 33\% were on inhaled bronchodilator. Conclusions: A small number of children had COVID-19. All infected children were with mild to moderate pulmonary symptoms and reacted satisfactory to the treatment. However, the importance of transmitting the virus and influence over children's health remains uncertain.

\section{Клнички истражувања}

\section{КЛИНИЧКИ КАРАКТЕРИСТИКИ НА КОВИД-19 КАЈ ДЕЦАТА ВО ИНСТИТУТОТ ЗА БЕЛОДРОБНИ БОЛЕСТИ КАЈ ДЕЦАТА-СКОПЈЕ}

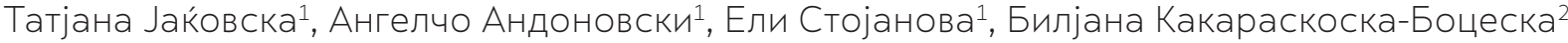

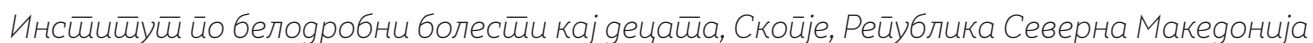

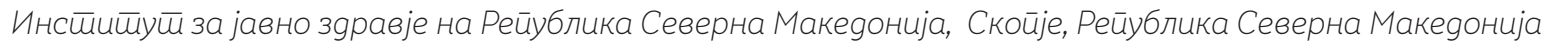

Цитирање: Јаќовска Т, Андоновски А, Стоја нова Е, Какараскоска-Боцеска Б. Клинички карактеристики на КОВИД-19 кај децата во Институтот за белодробни болести кај децата-Скопје. Арх J Здравје 2020;12(3). https://doi org/10.3889/aph.2020.5413

Клучни зборови: COVID -19, деца, белодробна болест, real-time reverse transcription polymerase chain reaction, макролиди.

*Кореспонденција: Татјана Јаќовска, Инсти тутот за белодробни болести кај децата-Скопје, Република Северна Македонија. E-mail: maretti98@yahoo.com.

Примено: 17-мај-2020; Ревидирано: 28-јун-2020; Ірифатено: 5-јул-2020; Објавено: 15 -дек-2020

Печатарски права: ${ }^{\circledR 2020}$ Татјана Јаќовска Оваа статија е со отворен пристап дистрибуирана под условите на нелокализирана лиценца, која овозможува неограничена употреба, дистрибуција и репродукција на било кој медиум, докодку се цитиреат оригиналниот(ите) втор(и) и изворот.

Конкурентски интереси: Авторот изјавув дека нема конкурентски интереси.

\section{Извадок}

Цел на трудот беше да се евалуираат клиничките карактеристики на COVID -19 и успехот на терапијата кај децата. Материјал и методи: Во студијата беа вклучени 218 педијатриски пациенти суспектни за COVID-19 инфекција, хоспитализирани во Институтот по белодробни заболувања кај децата-Козле, во период од 16-ти март до 19-ти јуни 2020 година. Сите пациенти беа тестирани за SARS-CoV-2 вирус во назофарингеален брис со real-time reverse transcription polymerase chain reaction (RT-PCR) во Институтот за јавно здравје на Република Северна Македонија. Клинички симптоми, рендгенграфии и лабораториски параметри беа вклучени во студијата. Резултати: Од вкүпно 218 хоспитализирани пациенти, само 9 (4,13\% ) беа со позитивен резултат за COVID -19. Од испитаните пациенти 59\% беа машки. Доенчиња под една година со потешка клиничка слика беа 44,4\%. Сите позитивни пациенти беа со средно тешки симптоми. 66,6\% од хоспитализираните деца беа со покачена температура и пулмонални симптоми и 22,2\% манифестираа гастроинтестинални симптоми. Макролидите беа лек на избор кај 88\%, а 77\% примаа интравенска терапија и 33\% инхалирачки бронходилататор. Заклучок: Мал број деца беа инфицирани со COVID -19. Сите позитивни пациенти беа со средно тешки симптоми, и дадоа добар одговор на спроведениот третман. Сепак, влијанието на овој вирус врз понатамошното здравје на децата како и улогата на децата во пренесување на вирусот останува недоволно познато. 


\section{Introduction}

Coronaviruses are a large family of viruses which may cause illness in animals or humans. In humans, several coronaviruses are known to cause respiratory infections ranging from the common cold to more severe diseases such as Middle East Respiratory Syndrome (MERS) and Severe Acute Respiratory Syndrome (SARS) caused by SARS-CoV-1 virus ${ }^{1}$. The most recently discovered severe acute respiratory syndrome coronavirus ${ }^{2}$ (SARS-CoV-2) causes so called COVID-19, an infectious disease that causes enormous morbidity and mortality in the whole world. This new virus and disease were unknown before the outbreak in Wuhan, China, in December 2019². COVID-19 is now a pandemic affecting mostly elderly, but also children in many countries globally.

Compared to adults SARS-CoV-1, MERS-CoV and SARS-CoV-2 seem to affect children less commonly and cause fewer symptoms. Preliminary evidence suggests children are just as likely to become infected with SARS-CoV-2 as adults, but are less likely to be symptomatic or to develop severe symptoms ${ }^{3,4}$. However, the importance of children in transmitting the virus and the importance of influence of this virus on child's future health and wellbeing is still uncertain $(7,8)$.

The aim of this paper was to evaluate clinical characteristics of COVID-19 and success of the treatment in children.

\section{Material and methods}

The study included 218 pediatric patients suspected for COVID-19, hospitalized at the Institute for Pulmonary Diseases in Children-Skopje, during the period from 16th of March to $19^{\text {th }}$ of June. All patients were tested for presence of SARS-CoV-2 virus in the nasopharyngeal swabs using LightMix SarbecoV E-gene plus EAV control, TIB MOLBIOL and LightMix Modular Wuhan CoV RdRP-gene, TIB MOLBIOL9. These tests present real-time reverse transcription polymerase chain reaction (RT-PCR) technology and were performed at the Institute of Public Health of Republic of North Macedonia in Skopje. We analyzed clinical symptoms, lung $\mathrm{X}$-rays and laboratory findings in this study.

\section{Results}

From a total of 218 patients tested for SARS-CoV-2, $41 \%$ were females, and 59\% males. According to age, all of them were from 5 days old to 15 years, but most of them belonged to the group under one year old (27.5\%), from 1 year - 2 years were $22 \%$ and $14.6 \%$ from 2 years - 3 years. Most of them originated from Skopje (84.4\%).

All COVID-19 patients had mild to moderate symptoms, $66.6 \%$ had high fever and pulmonary symptoms: increased cough, dyspnea, chest tightness, wheezing, sputum production, hemoptysis. 22\% had gastrointestinal symptoms: diarrhoea, vomiting/ nausea, abdominal pain. Most of the COVID-19 patients $(44.4 \%)$ were one year old or younger. 
Graph 1. Age distribution of patients with COVID-19

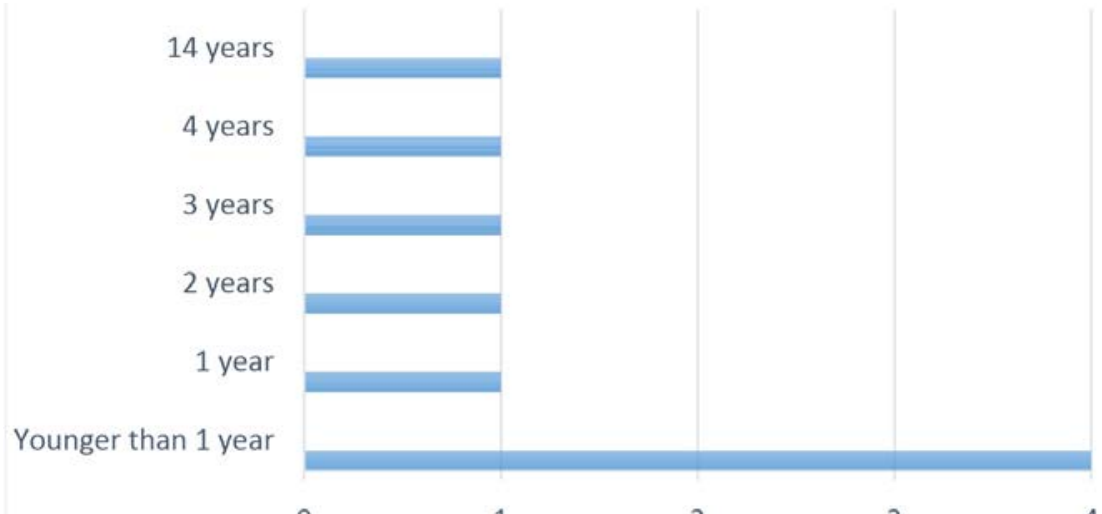

$\begin{array}{lll}0 & 1 & 2\end{array}$

rhea, vomiting/nausea, abdomi-

Clinical characteristics of COVID-19 in our patients were: nal pain

- Pulmonary symptoms: increased - Other symptoms: none of the cough, dyspnea, chest tightness, above

wheezing, sputum production, - But, most of the COVID-19 pahemoptysis tients had high fever and pul-

- Fever/General symptoms: fever, fatigue, headache, arthralgia/myalgia monary symptoms, and some of them had gastrointestinal and other symptoms (Graph 2).

- Gastrointestinal symptoms: diar-

Graph 2. Presentation of clinical characteristics in patients with COVID-19

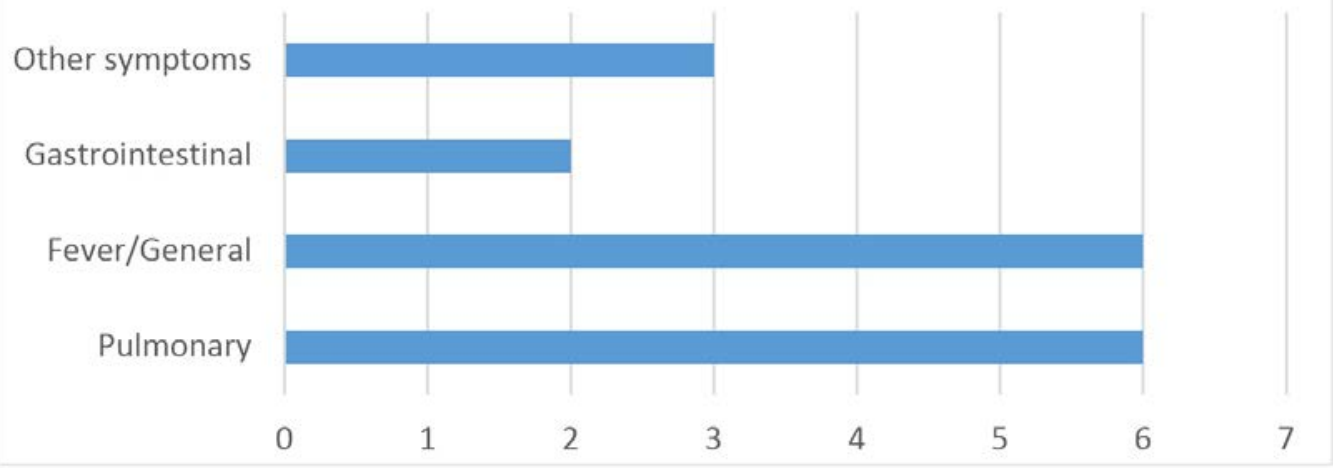

Individual symptoms in patients are presented in graph 3.

Graph 3. Individual symptoms in patients with COVID-19

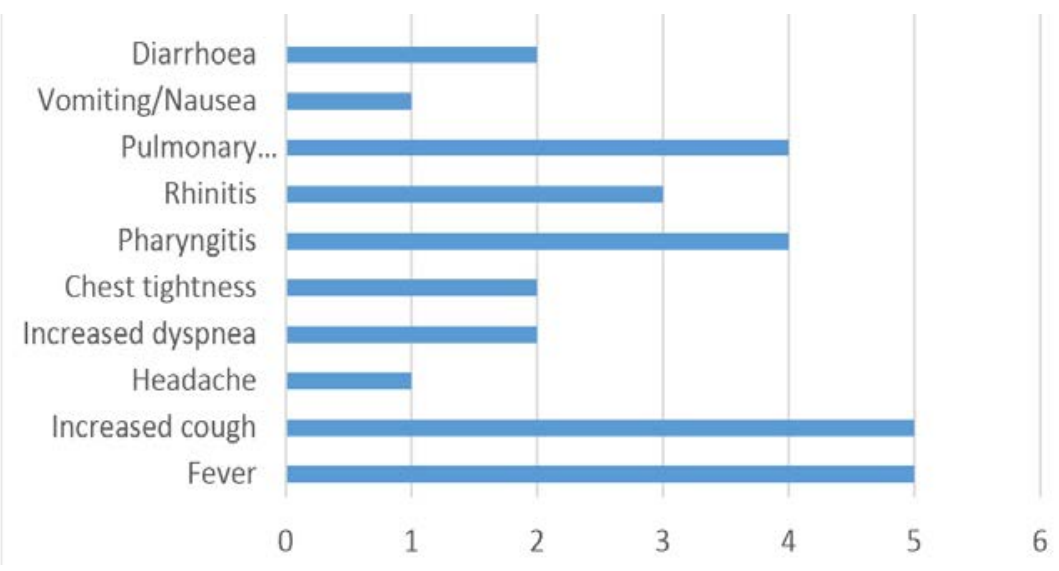


Table 1. Blood test results in positive patients with COVID-19

\begin{tabular}{|c|c|c|c|c|c|}
\hline & \multicolumn{5}{|c|}{ 宸 } \\
\hline & HGB & $\mathrm{RBC}$ & WBC & LYM\% & PLT \\
\hline Patient 1 & 11.6 & 4.41 & 14.8 & 3.5 & 469 \\
\hline Patient 2 & 12.7 & 4.35 & 10.2 & 17.4 & 236 \\
\hline Patient 3 & 12.4 & 4.41 & 5.4 & 43.3 & 170 \\
\hline Patient 4 & 12.1 & 4.7 & 40.6 & 22.8 & 419 \\
\hline Patient 5 & 12.7 & 4.45 & 7.1 & 16.7 & 229 \\
\hline Patient 6 & 10.6 & 4.51 & 20.3 & 7.1 & 289 \\
\hline Patient 7 & 13.2 & 5.61 & 9.7 & 48.6 & 255 \\
\hline Patient 8 & 10.3 & 4.6 & 8.3 & 65 & 525 \\
\hline Patient 9 & 11 & 4.02 & 15.3 & 25.3 & 420 \\
\hline
\end{tabular}

Laboratory analysis in patients with severity. We did not find elevated COVID-19

Lymphopenia, neutrophilia, high CRP, and high procalcitonin levels may be associated with greater illness serum alanine aminotransferase and aspartate aminotransferase levels, elevated lactate dehydrogenase levels in our patients (table 1).

Graph 4. CRP value in patients with COVID-19

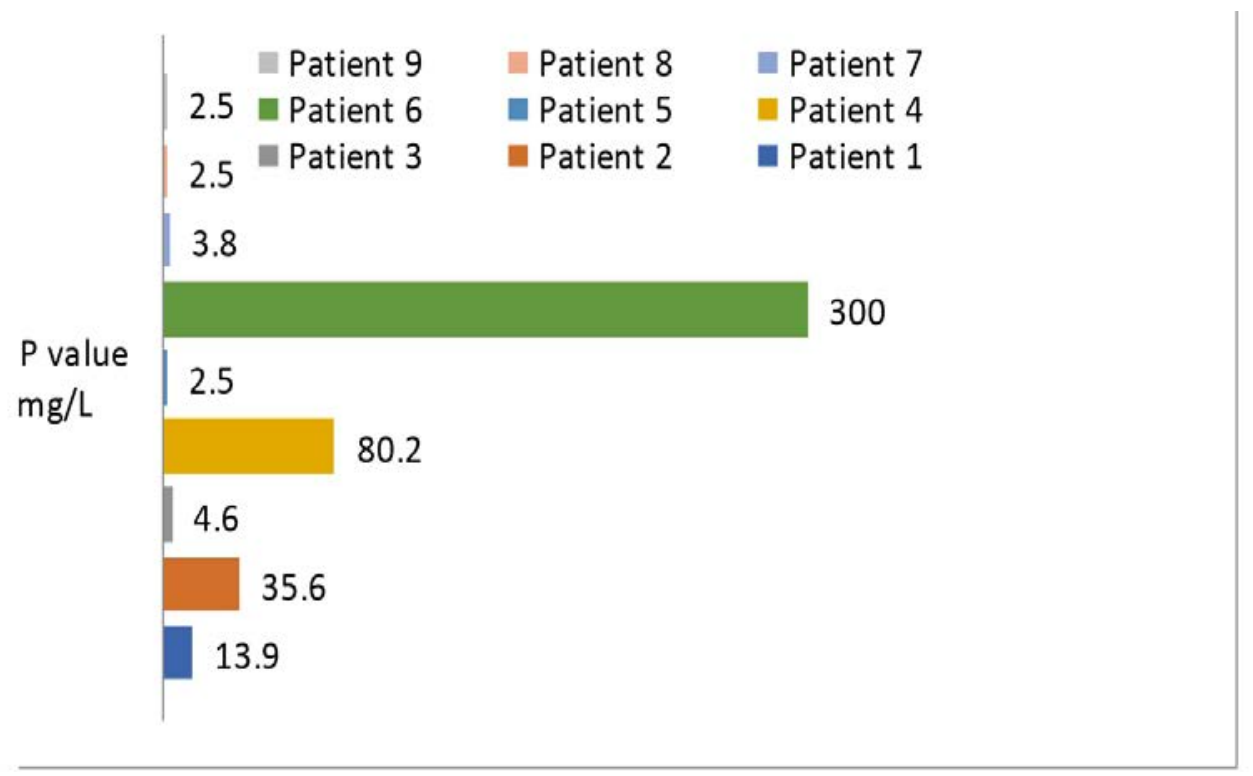

Urine culture - In only one Covid-19 Chest X-rays of children with patient, Escherichia coli ESBL+ was COVID-19 are presented in Picture 1 isolated. to Picture 3.

Blood culture - All blood cultures remained sterile after incubation. 
Picture 1. Chest x-ray of a 6-month-old child with COVID-19, with bilateral emphysema and bronchiectasis in the right lower lobe.

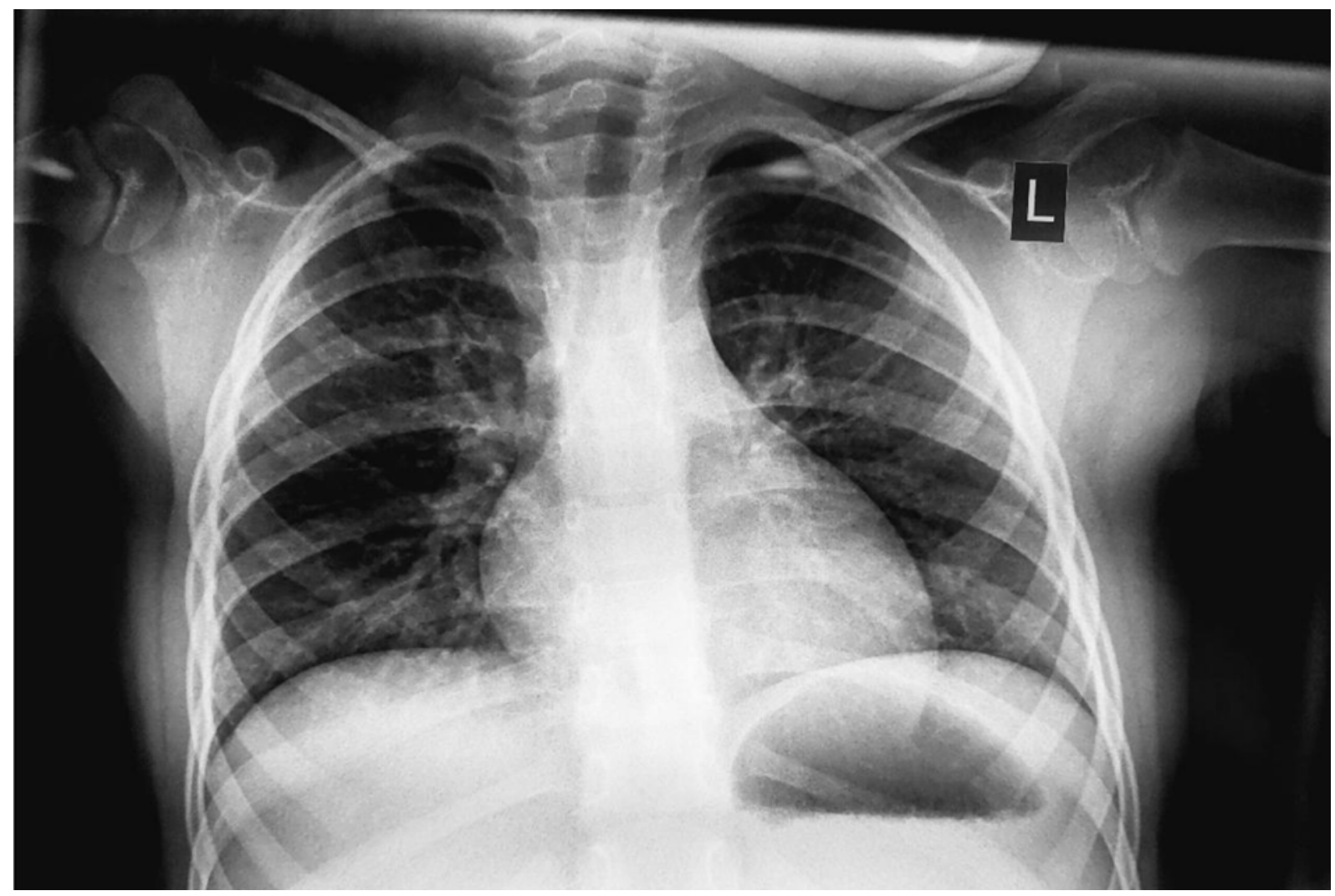

Picture 2. Chest $x$-ray of a one-year old child with $C O V I D=19$, with bilateral emphysema and bronchiectasis in the middle lobe.

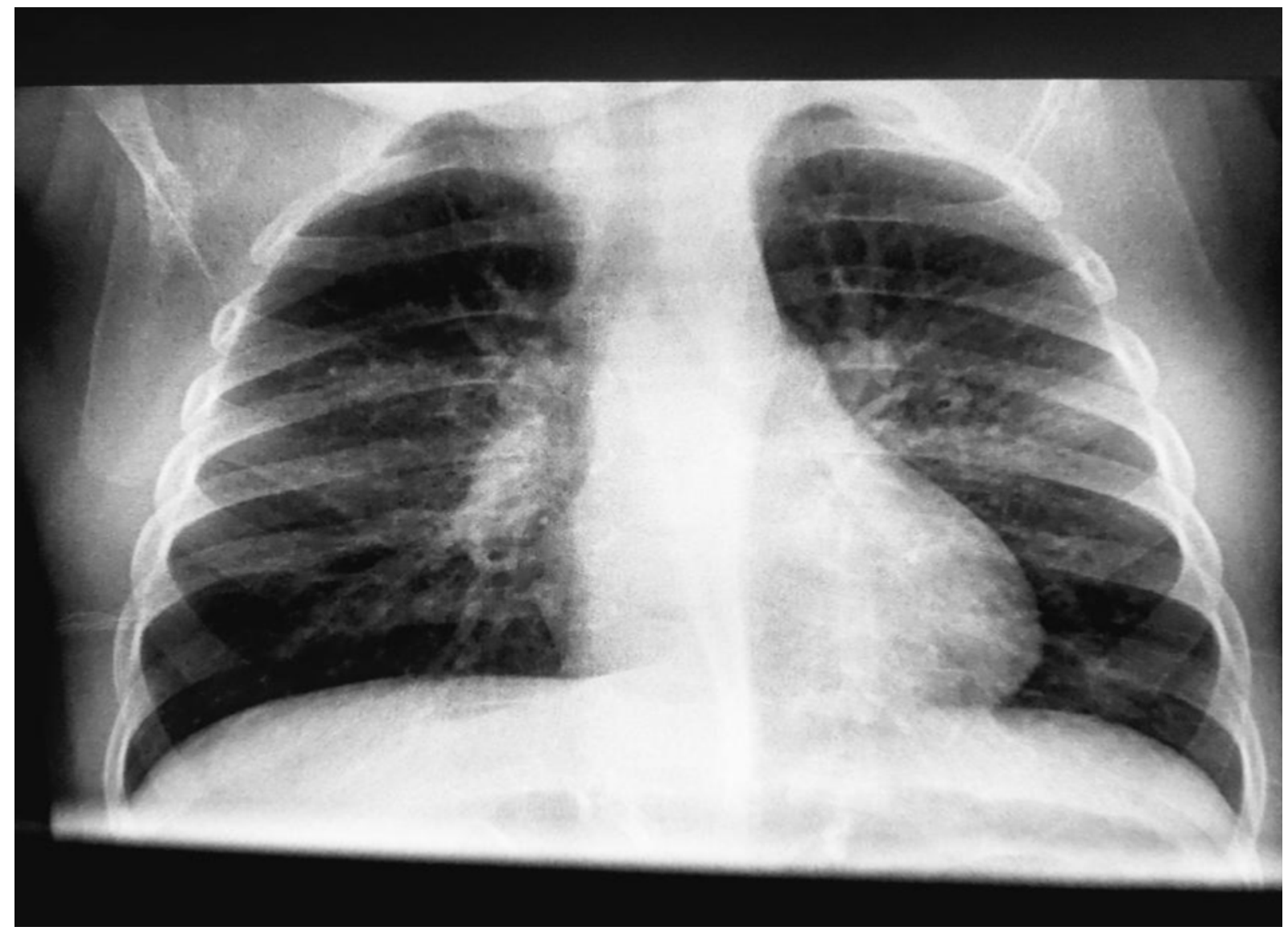


Picture 3. Chest x-ray of a 4-month-old child with COVID -19, with bilateral air-space consolidation.

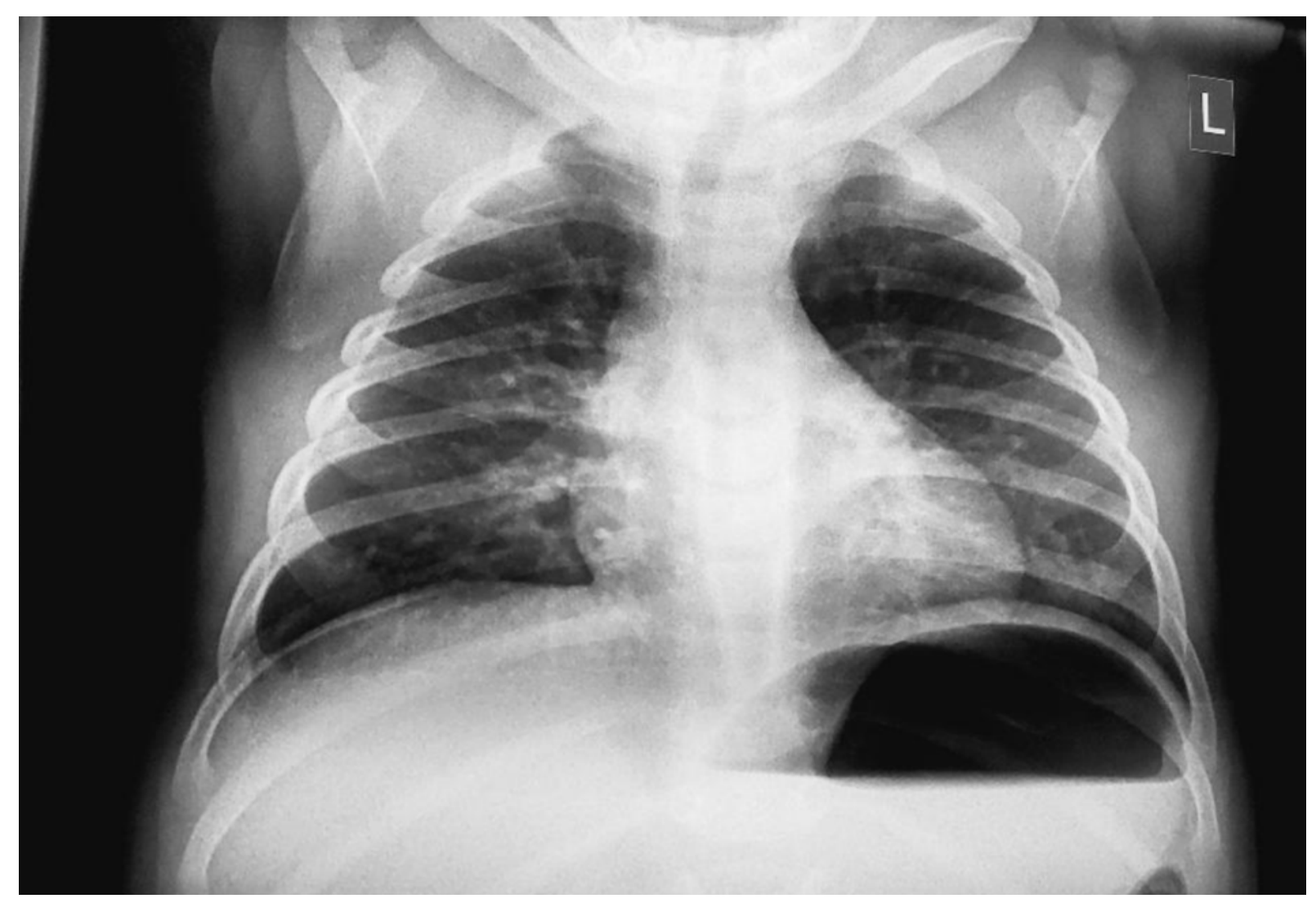

Table 2. COVID-19 drug treatment

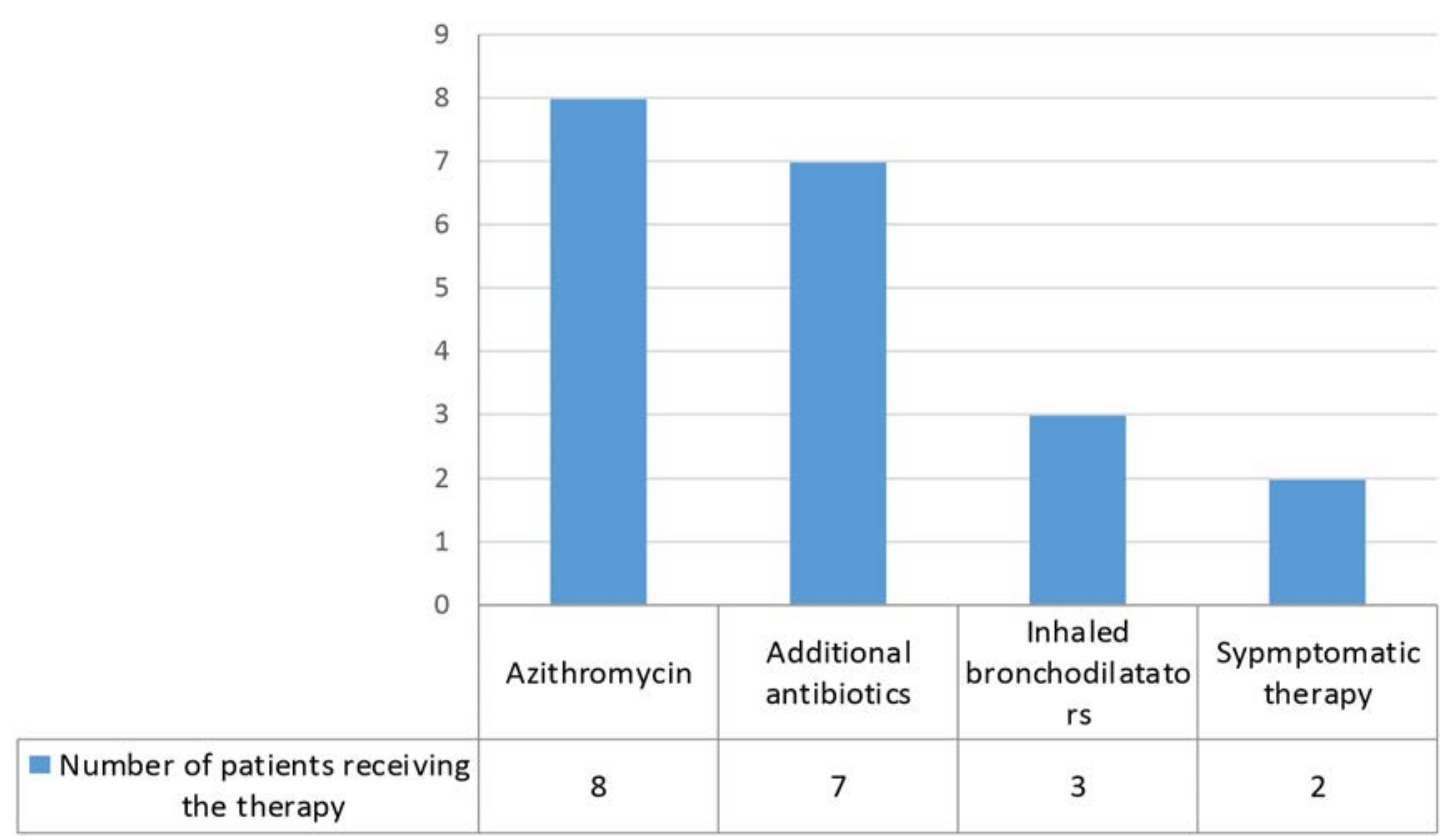

All COVID -19 patients were treated 34\% inhaled bronchodilator and had with azithromycin, but because of symptomatic therapy (Table 2).

moderate pulmonary disease many All COVID-19 patients reacted of them received intravenous third satisfactory to the treatment and they generation cephalosporins (77.7\%), left the hospital in a stable condition. 


\section{Discussion}

Children of all ages can become ill with coronavirus disease (COVID-19). But most of them who are infected do not become as sick as adults and some might not show any symptoms at all 1,2,3. Children also rarely experience severe illness with COVID-19. Children under the age of 1 (infants) are at higher risk of severe illness with COVID-19 4,5. This is likely due to their immature immune systems and smaller airways, which make them develop breathing issues with respiratory virus infections ${ }^{6,7}$. A study of more 2100 children with suspected or confirmed COVID-19 in China showed that $11 \%$ of infants had a severe or critical illness, about $7 \%$ of children ages 1 to $5,4 \%$ of those 6 to 10 years and $4 \%$ of those 11 to 15 years ${ }^{4,5,8}$.

During the stay in our hospital all patients had mild to moderate pulmonary and gastrointestinal symptoms. None of the treated patients needed oxygen therapy. All positive patients reacted well to the treatment and were discharged from hospital in a good condition.

\section{Conclusion}

This is the first published study of COVID-19 in children in the Republic of North Macedonia in which we found a small number of children with COVID-19. They had mild to moderate pulmonary symptoms and reacted well to the treatment. However, the importance of influence of this virus on child's future health and wellbeing is still uncertain, also transmission of the virus from asymptomatic children to other people is unknown.

\section{References}

1. Guan WJ, Ni ZY, Hu Y, et al. Clinical characteristics of coronavirus disease 2019 in China. N Engl J Med 2020;382:1708-20.

2. Cai J et al. A Case Series of children with 2019 novel coronavirus infection: clinical and epidemiological features. Clin Infect Dis 2020; ciaa198.

3. Dong $\mathrm{Y}, \mathrm{Mo} \mathrm{X}$, Hu $\mathrm{Y}$, et al. Epidemiology of COVID-19 among children in China. Pediatrics 2020;145(6):e20200702.

4. Lu X, Zhang L, Du H, et al. SARSCoV-2 infection in children. $\mathrm{N}$ Engl J Med 2020;382:1663-5.

5. Wei M, Yuan J, Liu Y, Fu T, Yu $\mathrm{X}$, Zhang ZJ. Novel coronavirus infection in hospitalized infants under 1 year of age in China. JAMA 2020;323(13):1313-1314.

6. Bernheim A, Mei X, Huang M, et al. Chest CT findings in coronavirus disease-19 (COVID-19): relationship to duration of infection. Radiology 2020:200463.

7. Bai HX, Hsieh B, Xiong Z, et al. Performance of radiologists in differentiating COVID-19 from viral pneumonia on chest CT. Radiology 2020:200823.

8. Xie X, Zhong Z, Zhao W, Zheng C, Wang F, Liu J. Chest CT for typical 2019-nCoV pneumonia: relationship to negative RT-PCR testing. Radiology 2020:200343.

9. World Health Organization. Coronavirus disease (COVID-19) pandemic. Available at: https:// www.who.int/docs/default-source/ coronaviruse/situation-reports 